\title{
Reconsidering the Dead in Andres Serrano's The Morgue: Identity, Agency, Subjectivity
}

\section{Andrea D. Fitzpatrick}

Volume 33, numéro 1-2, 2008

Medical Tabulae: Visual Arts and Medical Representation Tabulae médicale : arts visuels et représentation médicale

URI : https://id.erudit.org/iderudit/1069545ar

DOI : https://doi.org/10.7202/1069545ar

\section{Aller au sommaire du numéro}

\section{Éditeur(s)}

UAAC-AAUC (University Art Association of Canada | Association d'art des universités du Canada)

\section{ISSN}

0315-9906 (imprimé)

1918-4778 (numérique)

\section{Découvrir la revue}

Citer cet article

Fitzpatrick, A. D. (2008). Reconsidering the Dead in Andres Serrano's The Morgue: Identity, Agency, Subjectivity. RACAR : Revue d'art canadienne / Canadian Art Review, 33(1-2), 28-42. https://doi.org/10.7202/1069545ar

\section{Résumé de l'article}

Cet article propose de reconsidérer l'oeuvre de l'artiste contemporain américain Andres Serrano, notamment de sa série d'épreuves chromogéniques datant de 1992 et intitulée The Morgue qui expose un groupe de cadavres photographiés dans une morgue réelle. Je parle de reconsidérer l'oeuvre de Serrano parce que la série en question a déjà fait l'objet de plusieurs études. Cependant, les discours critiques à propos de cette série ne se sont jamais penchés sur les conséquences de cette invasion de la vie privée pour les morts. Dans cet article, j'explore la manière dont Serrano manifeste sa prise de conscience face à la vulnérabilité des morts, non pas en abordant l'éthique de ses choix, mais en examinant comment cette réification des corps perpétue néanmoins une forme de subjectivité posthume, question rarement abordée dans les domaines de l'histoire de l'art et de la théorie culturelle. L'encadrement et la mise au point, les titres, les choix esthétiques, la fragmentation des corps (qui tantôt dissimule, tantôt privilégie le visage), ainsi que le caractère d'infraction d'une intervention faite à la dérobée en milieu mortuaire : tous ces éléments affectent les types d'identité qui émanent de la spécificité des sexes et de connotations diverses accordant à la pathologie et à la criminalité une part significative. La capacité d'agir de Serrano se révèle indirectement dans ses travaux, lorsque l'artiste transgresse l'ordre du pouvoir généralement accordé aux vivants et retiré aux morts (effet de présence des corps, capacité de contact, d'accès visuel). En étendant aux morts une notion de subjectivité qui emprunte à la pensée de Judith Butler, je démontrerai que les cadavres de Serrano restent intensément vulnérables à la violence qu'implique toute représentation.
Tous droits réservés @ UAAC-AAUC (University Art Association of Canada | Association d'art des universités du Canada), 2008
Ce document est protégé par la loi sur le droit d'auteur. L’utilisation des services d'Érudit (y compris la reproduction) est assujettie à sa politique d'utilisation que vous pouvez consulter en ligne.

https://apropos.erudit.org/fr/usagers/politique-dutilisation/ 


\title{
Reconsidering the Dead in Andres Serrano's The Morgue: Identity, Agency, Subjectivity
}

\author{
Andrea D. Fitzpatrick, University of Ottawa
}

Résumé

Cet article propose de reconsidérer l'œuvre de l'artiste contemporain américain Andres Serrano, notamment de sa série d'épreuves chromogéniques datant de 1992 et intitulée The Morgue qui expose un groupe de cadavres photographiés dans une morgue réelle. Je parle de reconsidérer l'œuvre de Serrano parce que la série en question a déjà fait l'objet de plusieurs études. Cependant, les discours critiques à propos de cette série ne se sont jamais penchés sur les conséquences de cette invasion de la vie privée pour les morts. Dans cet article, j'explore la manière dont Serrano manifeste sa prise de conscience face à la vulnérabilité des morts, non pas en abordant l'éthique de ses choix, mais en examinant comment cette réification des corps perpétue néanmoins une forme de subjectivité posthume, question rarement abordée dans les domaines de l'histoire de l'art et de la théorie culturelle. L'encadrement et la mise au point, les titres, les choix esthétiques, la fragmentation des corps (qui tantôt dissimule, tantôt privilégie le visage), ainsi que le caractère d'infraction d'une intervention faite à la dérobée en milieu mortuaire : tous ces éléments affectent les types d'identité qui émanent de la spécificité des sexes et de connotations diverses accordant à la pathologie et à la criminalité une part significative. La capacité d'agir de Serrano se révèle indirectement dans ses travaux, lorsque l'artiste transgresse l'ordre du pouvoir généralement accordé aux vivants et retiré aux morts (effet de présence des corps. capacité de contact, d'accès visuel). En étendant aux morts une notion de subjectivité qui emprunte à la pensée de judith Butler, je démontrerai que les cadavres de Serrano restent intensément vulnérables à la violence qu'implique toute représentation.

"N 1 Jothing that matters can happen to the dead, and nothing that happens to them can matter," writes novelist Michael Dibdin in his description of the autopsy procedures performed upon two corpses that he witnessed as a visitor to a pathologist's lesson.' Dibdin's ironic tone suggests that, on the contrary, the dead are subject to a great deal of manipulation by the living, which causes the author, if not the cadavers, some degree of unrest: "Throughout their ordeal, both corpses radiate a total passivity, a massive indifference, like stuffed toys whose mutilated features and unstitched scams need cause no anguish." 2 Indeed, as cultural theorist Elisabeth Bronfen argucs, the dead, especially when female, are seriously at risk of representational violence in works of art and in criticism. This is due to the "fictionalization" or acstheticization of the material experience of death, and to the occlusion of biographic details, which de-individuate the dead. ${ }^{3}$ Dibdin's and Bronfen's views help introduce the work of American artist Andres Serrano (b. 1950), namely, his 1992 series of almost three dozen, large-scale Cibachrome photographs entitled The Morgue, which depicts a diverse group of human corpses in an unspecificd, but actual morgue. I would like to explore the ways in which Serrano shows his awarencss of the vulnerability of the dcad, not by recognizing it as an ethical paradigm, but by exploiting and reifying it, perpetuating a subjectivity for the dead that is disrespectful, if not also wounding. I intend to demonstrate how the proclivity of the dead to "endure" violence occurs not only at a material level but also at a discursive level and through artistic representations (involving images, language, and the cultural systems through which they are understood). This representational violence constitutes the posthumous production of their subjcctivity. The ways in which the appearance of the dead in Serrano's photographs contributes to (or, more precisely, contorts) the process of subjectivity for the dead are important, becausc in cultural thcory, posthumously produced subjectivity is rarely considered. Yet, I have been advised by some collcagues that "the dead are not vulnerable." The seeming invulnerability of the dead is precisely what is being questioned here. Fven in death, subjects continue to be vulnerable to representations and to the names onc does or does not call them.

I call this a reconsidcration of Serrano's work because his series is neither new nor unexamined by the academic, curatorial, and art-critical communities. However, while The Morgue has received much attention, none of the writing focuses on the stakes involved for the dead. ${ }^{4}$ And there are stakes. In contrast to previous studies, my interest revolves not around how Serrano's work contributes to a photographic aesthetic for postmodernism (where the history of Western religious painting and the sacredness of its subject matter are simultaneously invoked and made profane), but rather with the issuc of agency. Agency is shown in Serrano's works, but in a one-sided way, when Serrano takes advantage of the imbalance of power that exists between the living and the dead (at the level of embodiment, contact, vision, and access). This dramatically affects our view of the dead and the identities that are attributed to them. By extending the notion of subjectivity to the dead, wc will see how they are acutely vulnerable to representational violence and why this is a problem.

I would also like to emphasize that a significant precursor to Serrano's series in the history of visual culture is not only Western religious painting (as has been suggested) but also a lineage of medical representations explicitly linked with the bodies of dead criminals and hyper-sexualized or pathologized female bodies. What needs attention is the extent to which the criminal and pathological identity categories that surround the 
dead in The Morgue are largely Serrano's construction, attributes forcibly affixed to the corpses he represents. The framing and focus, aestheric choices, fragmentation of bodies (which most often occludes the face, but sometimes shows only the face), the morgue environment in which Serrano furtively worked, as well as other connotative devices, imply identitics sharply inflected by issues of criminality, gender-specificity, and pathology.

Three key terms-identity, agency, and subjectivity-need to be clarified in order to understand the issues that, I propose, are central to Serrano's work. Identity involves a quality or comprises a set of qualitics, attributes, or characteristics that are considered important in specifying, individuating, and defining the self, and for being recognized in specific ways by others. Identity is a notion that signifies singularity and distinction from others but also encompasses the identifications forged with groups or communities that share similar identity catcgories. 5 Elizabeth Grosz summarizes this understanding as follows: "Identity comes only as a result of a dual motion of the internalization, an introjection of otherness, and the projection onto the other of some fundamental similarity or identification with the subject." 6 Grosz also proposes a unique way of thinking about identity with an evolutionary twist, to more emphatically involve the body's temporality: "Identity is thus a synthesis of what one has done (and has been done to one) but also a dissipation of patterns and habits in the face of an open future."7 Keeping the temporality of identity in mind paves the way for understanding identity as changing and fluid rather than solid, and how the dead are posthumously subject to a variety of identity categorics different from what they may have chosen in life.

Agency, as Kath Woodward has succinctly argued, is "the degree of control which we ourselves can exert over who we arc." 8 Agency could be vicwed as the ability to name or claim identity from onc's own perspective, the power to make (or remake) oneself visible and audible within a given social matrix, and the ability to assert oneself in an embodied, political, or social way. This potential is viewed by certain paradigms of identity politics and practices in the visual arts as important when the social matrix is exclusionary.9 Agency is closely related to the development of identity because an agent is an individual who holds the capacity to assert her or his own point of view, in agreement with or opposition to given values (normative or otherwise), with or against oppressions or prohibitions that ensue from socio-cultural, institutional, lcgal, economic or interpersonal practices. ${ }^{10}$ The voice, visuality, touch, and embodiment are considered dimensions of agency (i.e., resources for the agent to assert her or his self). One of my goals here is to demonstrate how they are centrally implicated in the processes of representation by which subjectivity emerges for the dead.
Modern subjectivity is the psychic, linguistic, social, and institutional process of recognition and attribution that grants, inaugurates, or intcrpellates subject status. It underlines a decentering of the self and should be seen as a process necessitating a temporal matrix, involving and influenced by the recognition of others and regulatory institutions, in addition to the confining and confirming effects of culturc and language, which should be understood as preceding the subject's entrance into social or cultural environments. (One becomes a subject not because one speaks, but because one is spoken of, spoken to, or otherwise addressed by representations.) Subjectivity, as I understand it, is an ongoing series of effects involving language, images, cultural and political institutions (as well as their discourses), embodiment, names, and identity catcgories, which are repeated over time. These effects form the notion of the subject, who must always be assumed to be under construction, a work in progress, changing and contingent, less a source of agency than a scene or sight through which the effects of power are materialized. My views on subjectivity are informed by Judith Butler's work, in parcicular, Bodies That Matter: On the Discursive Limits of 'Sex' (1993), where she charts a position berween radical constructionism and the (in)accessibility of the fleshy materiality of the body (due to its bcing densely coded by signification). Butlcr addresses many states of social exclusion in which subjects lack agency, and the way she describes the painful subjective experiences of misogyny, homophobia, and racism-in terms of extreme abjection (i.e., as "unlivable," or "uninhabitable")—are as dire as death itself." Despite their usefulness, if we extend Buclcr's theories to the dead, wc bcgin to see the limits of certain representational systems: limits in their ability to take the dead into consideration. If the dead appear to be already beyond the most abject social states that define the living, how then is access or understanding forged?

The particular usefulness of Butler's work lies in her distinction between the materiality of the body and the discursive process of materialization by which subjectivity and identity can be understood. And, as Butlcr puts forth in Excitable Speech: A P'olitics of the Performative (1997), the process of subjectivity implicates not only bodies but also the names they are called (both descriptive and proper), and therefore cntails linguistic systcms by which subjects are categorized and recognized or, alternatively, insulted and demeancd. ${ }^{12}$ Butler discusses speech acts (i.e., performatives) and, by focusing on the injurious effects of certain namcs, demonstrates the agency that adheres to language: one becomes a subject through it (by being named), but also becomes vulnerable to its effects, as hate speech makes evident. Butler's terminology for the materialization of gender (or other faccts of identity, such as race) as performative is rather misleading, for the word suggests that the individual is an agent who willfully chooses the identity category. 13 


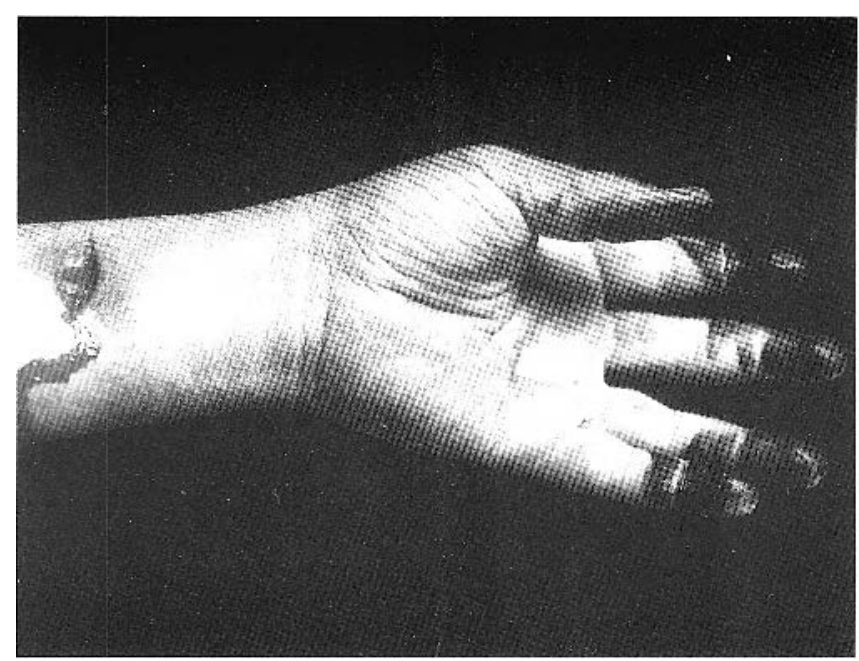

Figure 1. Andres Serrano. The Morgue (Knifed 10 Deulh. 1). 1992. Ciba. chrome photograph, $125.7 \times 152.4 \mathrm{~cm}$ (C) Andres Scrrano: courtcsy of Paula Cooper Gallery. New York).

In fact, the normative standards as to what can or cannot be understood (or claimed) as an identity catcgory cxist prior to the individual, and regulate in advance those positions that are open and those that would be deemed unintelligible or othcrwise abject. ${ }^{14}$ Butler's performative theory of subjectivity is important here because her understanding of the way discourse "materializes" subjectivity, as the manifestation of power relations circulating around (but not inherent in) the cmbodied subject, is what occurs to the dead subjects in Scrrano's The Morgue. ${ }^{15}$

Another of Butler's insights is that the dark side to agency—its Achilles heel, if you will—is vulnerability: "Ihc body implies mortality, vulnerability, agency: the skin and the flesh expose us to the gaze of others, but also to touch, and to violence, and bodies put us at risk of becoming the agency and instrument of all these as well." 16 Butler conceives of embodied subjectivity as a double-edged process in which agency must bc understood as contingent upon the potential for vulnerability. While Butler envisions this dual potential (for agency to shift into vulnerability) to exist equally between subjects as well as within one subject, the situation of Serrano in rclation to his subjects in The Morgue is not reciprocal. Exposed to the violence inherent in the visibility of each image, the corpses in Scrrano's photographs are involved in a scene where the agency is his and the vulnerability is theirs. If the dead are spectres of failed embodiment, the utter aporia of agency hovering at the limits of (or even beyond) recognition, the sight of agency's evacuation, one begins to understand how the subjectivity of the dead is painfully materialized for them.

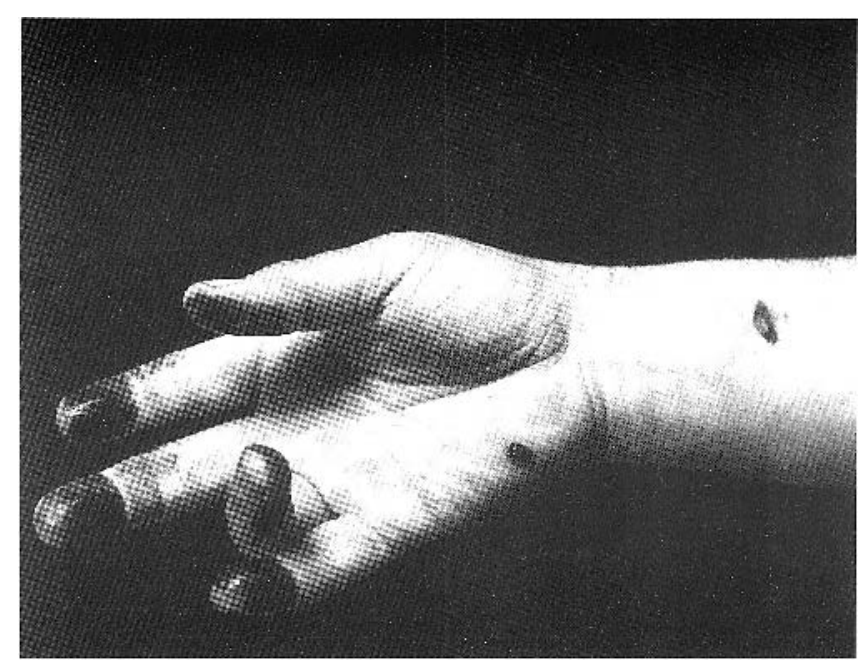

Figure 2. Andres Serrano. The Morgue (Knifed to Deuth, 11), 1992. Ciba chrome photograph $125.7 \times 152.4 \mathrm{~cm}$ (@) Andres Serrano; courtesy of Paula Cooper Gallery, New York).

\section{Criminal Identity}

'There are many layers of violence in Andres Serrano's series the Morgue. In Knifed to Death, I (fig. 1), we sce the palm of an open, outstretched hand in which each fingertip has been sloppily stained with black ink. Knifed to Death, II (fig. 2) offers a pendant view of the other hand positioned more clegantly, with the ring finger bent gently to meet the thumb. Ihe titles of the works tell the viewer that the deceased is a victim of violence. The deep curs on the arm, from which blood flows so freshly it appears to be still wet, visually repcat the information of the title. In both works, a body fragment stands in for its entircty and functions in a metonymic way. While the body to which these hands are apparently connected, and any other details of the individual's appearance, are excluded from vicw, one identification has already taken place within the frame. The ink stains on the fingertips indicate that fingcrprinting was done by the police. This "identification" essentializes the individual in terms of the manner of death, coding the deceased as a suspect in the very crime by which (s)he is the fatality. Morcover, this identity is spoken only beyond the frame, within police archives, never to be revealed to the viewer, who cannot even be surc of the subjcct's gender. This subject is reduced to one or the other side of a dance of violence-the perpetrator or the victim-both equally implicated. The unwashed hands result in the deceased's identity being blackened by the machinery of the criminal justicc system.

That the hands of the dead would have felt nothing throughout these posthumous ordeals (being handled by the policc, by the pathologist, and by the artist) is a central fascination of the 
work. While the fingertips of the dead were touched by ink, guided by the hands of officers or morgue orderlies, touch was in the service of institutional rather than interpersonal or sensorial knowledge. The palms and the fingertips seem to implore the viewer's approach by the reaching, gesturing poses, lending a beckoning aura to the images, especially whon viewed as pendants. Any sense of touch, however, is soiled by the wash of criminality that places the dead out of the range of identification for the average viewer. The violent "touches" that fatally mark the corpse and the lack of sensation "felt" by it coexist in difficult tension in the image. Although the fingertips of the deceased danglc close to the viewer, they withhold identity, so that the deceased remains not only faceless but also anonymous, and, in a metaphorical sense, untouchable. Thesc images hide the identity of the dead yet simultaneously reify identity as an act of violence. Although the belief that Serrano hid the identities of the deccased is the most common argument in defence of his work (i.e., that he "protected" or "obscured" the identities of the deceased), this bccomes a striking paradox bccausc of the criminal identities that are offered in their place.

The production of criminal identity is cxaggerated by the environmental connotation of the morgue. The central cthical paradigm that arises from Serrano's choice to depict these subjects in the context of a morgue has been overlookcd by the scholarly and art-critical discourse. For example, in the most significant art-historical study of Serrano's scrics, Susan Douglas asks, "Was the dcath natural or the result of misadventure?"17 Douglas rcads the variety of deaths as a gucssing game played by the viewer that mimics the investigative work of the pathologist. While Douglas's article establishes Serrano's work as a postmodern transgression (that is, at once referencing the Western art-historical canon while inverting, or more accuratcly, perverting it), her question does not consider how the corpses are already categorizcd.

There arc, importantly, different types of morgues: those associated with hospitals and their departments of pathology (to which the corpses resulting from non-suspicious deaths would be sent for medical autopsy), and those associated with the city or state (to which any corpses requiring a forensic autopsy would be sent). ${ }^{18}$ As explained by pathologist Eugene A. Arnold, "The forensic autopsy is conducted when a person dies for an unknown reason.... In this type of autopsy there rarcly is a clinical history available, and the starting data consists of a police report." I9 At first glance, the spectrum of corpses represented in The Morgue series appears to reflect the indiscriminate power of death to strike a full range of society. Serrano seems not to have chosen his subjects so much as photographed the spectrum of humanity that cntered the morgue during a threc-month period (according to Robert Hobbs, he photographed 95\% of them). 20 They are in fact a highly specific group, cloaked by an epistemo- logical framework that made forensic analysis necessary. If the titles of the works and the traumatic conditions of the corpses are an accuratc indication, the type of morgue in which Serrano worked is clearly forensic. All the deaths fall under the category of "suspicious," such as (for example): the notorious Rat Poison Suicide triptych, in addition to Multiple Stabbing, Hacked to Death, Burnt to Death, Death by Asphyxiation, Death by Drowning, Gun Murder, Death by Fire, Sleeping Pill Overdose, John Doe Baby, II, and Homicide Stabbing. It is precisely the uncertainty surrounding the bodies and the manners of death that ties the dead primarily to the state's criminal justice system (rather than to the medical system) in a way that is crystal clear, constructing their identities in a specific way-through the framework of horrific violence, neglect, and criminality.

The works in The Morgue have been interpreted as arristic feats finding beauty in the macabre, rather than involving the material and logistical implications of Serrano's secretive engagement with this highly restricted space. Serrano situates the bodies as faceless portraits, that is, as paradoxical variations of the genre that deliver substantial information regarding the morphologies of the bodies, all the while withholding the personal (i.e., nominal and biographic) identities associated with them. It is the apparent de-individualization of the corpses in Serrano's The Morgue that is claimed in order to preclude the possible charge that his work is exploitative. This is expressed by Douglas in her defence of Serrano's work: "Serrano's practice is, fundamentally, admittedly, an aestheticization of death."21 Douglas interprets Scrrano's accomplishment as a look at death in general, rather than, as I would argue, the dead in particular. According to Douglas, "Serrano speaks of representation and then of social powers and cultural bodies rather than of individuals who are dead or alive."22 Douglas compares Scrrano's work to Cindy Sherman's untitled series (1992) of similarly large-scale colour photographs of uncanny, often grotesquely assembled doll-figures and calls them "photographed replicants." 23 With this comparison, Douglas fails to take into account the reality of the corpses in The Morgue and favours an exploration of the discourse of visuality: "Serrano's practice must be acknowledged, after all, as both productive and reproductive of postmodernism's $s(t)$ imulations and seductions." 24 The bodies in Serrano's work are not, of course, movie props or dolls but actual corpses, and whilc this is precisely where the transgressive aura of his work originates, it also causes its ethical problcms. The dead are not, in Douglas's words, "merely texts," but the physical remains of those whose subjectivities continue to be performed by the artworks. ${ }^{25}$ Serrano's intense focus on the faces and body parts of real (that is, non-fictional) individuals indicates a particular stream in contemporary photographic practices. This stream is different from the constructed or fabricated work of his American peers (Sherman and Laurie Simmons, for example), and 


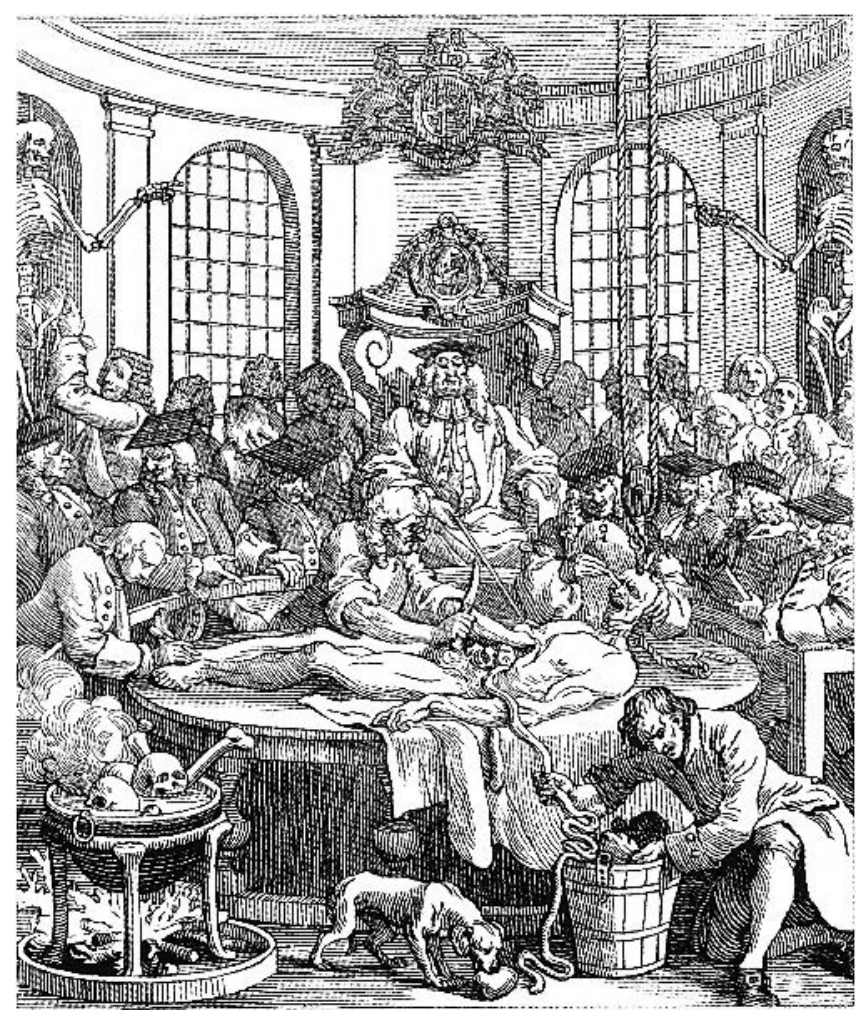

Figure 3. John Bell after William Hogarth. The Reward of Cruelty. Woodcut print from The Four Stages of Cruelty, 1750-51, $45.5 \times 38.5 \mathrm{~cm}$ (C) British Library Board)

from those Canadian artists described by Pcnny CousineauLevine in her important contribution to this discoursc, Faking Death: Canadian Art Photography and the Canadian Imagination (2003), despite the fact that the melodramatic film-noir aesthetic at times appears similar.

Although the aesthetics of fragmentation has been a common paradigm for photography ever since Surrealism, in Serrano's work "the body in pieces" comprises a social, politicized paradigm of painful states specific to the postmodern era: abjection, the AIDS crisis, the violence of homophobia, feminist and anti-racist protest, the questioning of normative identity categories, and the disbelief in psychological wholencss. In this regard, Serrano's work should be compared to that of other photographic artists of his generation, namely, Nan Goldin, David Wojnarowicz, and AA Bronson, who have represented AIDS-related deaths with an unflinching style ostensibly related to Serrano's. I have in mind Goldin's series of her charismatic friend Cookie Mueller from the late 1980s, as well as that depicting her Parisian friends Gilles Dussein and Corscho of 1992-93; Wojnarowicz's post-mortem triptych and prose memorializing the death of his beloved mentor Peter Hujar (1990);

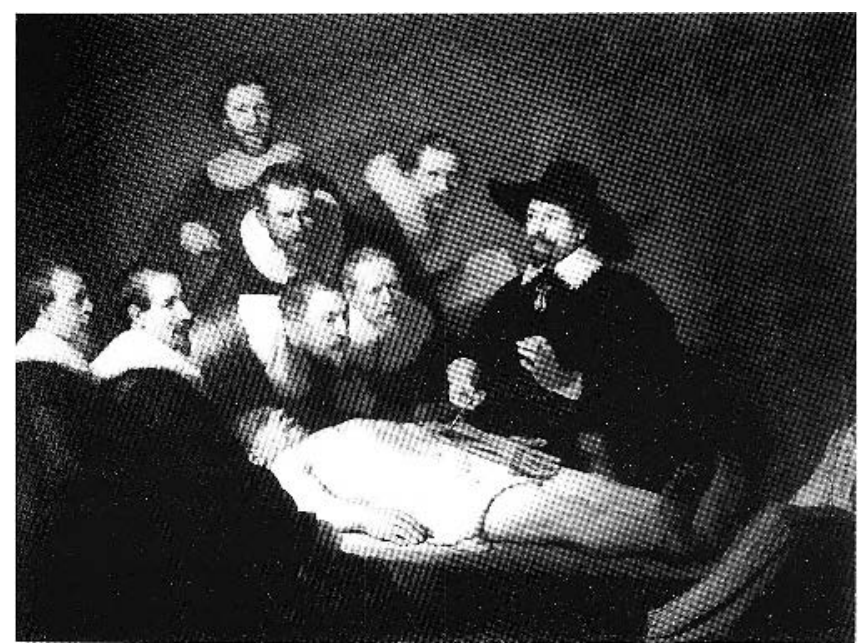

Figure 4. Rembrandt van Rijn, The Anatomy Lesson of Dr. Nicoluas Tulp. 1632. Oil on canvas, $169.5 \times 216.5 \mathrm{~cm}$ (Courtesy of Royal Picture Gallery Mauritshuis, The Hague).

and Bronson's monumental commemorations of the deaths of his General Idea partners in life and art, Jorge, February 3, 1994 (1994-2000) and Felix, June 5, 1994 (1994-99). Serrano's series clearly lacks the devotional, honorific intentions of these artists, who articulate a prior emotional engagement with their dying and dead subjects, who are intimate friends or lovers. The portraits by Goldin, Wojnarowicz, and Bronson never suggest the radical dislocation of personal identity enacted by Serrano's ink-stained hands (in his Knifed to Death duo) because the narrative dimensions of their series contextualize their subjects and connect their bodies (or body parts) to clearly identified sources. Such photographic portraits show it is possible to portray the bodies of the dead (even by using compositional devices like radical fragmentation, airless proximity, and near-exploitative exposure) without necessarily enacting representational violence, without subjecting the dead to alterity or to isolation.

The premium Serrano places on aesthetics or, in curator Wendy Steiner's words, "the formal argument," has, in most contexts, justified the works so that no further inquiry into the implications of his visual revelations was necessary. ${ }^{26}$ Much of the interest in Serrano's work arises from his successful dem- 
onstration of the relationship between the history of painting and postmodern aspirations for photo-based art. Scrrano achieves this partly with his cxploration of the visual potential of skin surfaces and the sensual details conveyed by them. The polychrome Hesh is like stained fabric, and the way it is punctuated by hairs, wounds, crevices, and jewel-toned body Huids ooying from wounds is excecdingly painterly. Moreover, the superb technical skill with which he captures these closerange views is not a feat of digital altcration, but of deft handling of his analogue medium. Serrano's technical virtuosity is displayed to full benefit by the Cibachrome developing-printing process, which is known for reproducing 4-by5-inch photographic transparencics with exquisitc detail and sumptuous colour on a grand scalc. Scrrano's seductive aestheticism in these works, and all the others in The Morgue scries, is apparent not only in the rich colours and subele tonal varia-

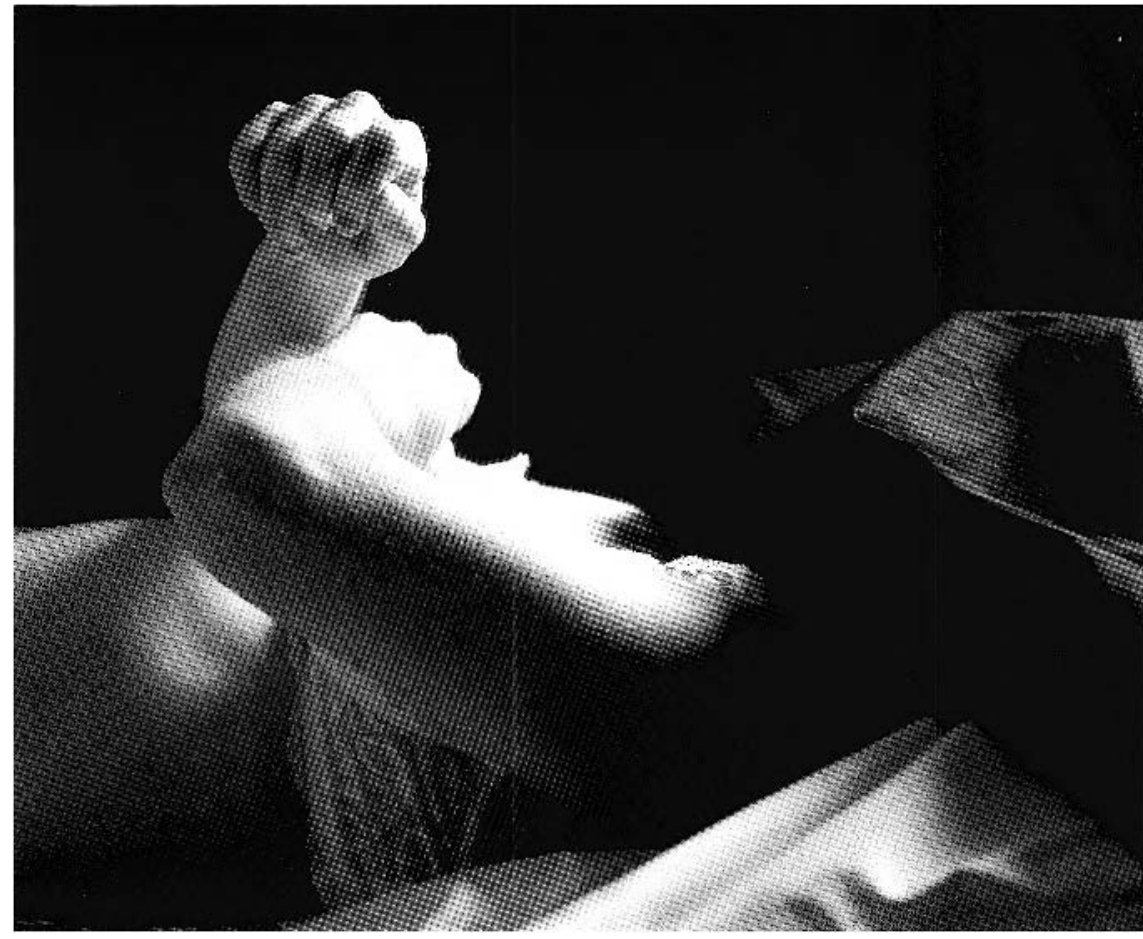

Figure 5. Andres Serrano, The Morgue (Rol. Poison Suicklc, 1). 1992. Cibachrome pholograph, $125.7 \times 152.4 \mathrm{~cm}$ (C) Andres Serrano; courtesy of the artist). tions but also in the many references to the Italian Renaissance (Mantegna, for example) or to the carly Baroque (Caravaggio's earthy realism, in particular). These references are seen in the noble grace of the bodies' extremitics, the chiaroscuro or tenebroso modelling of flesh by golden light, the manipulation of body bags to achicve the effects of classical drapery, and the glorious "heroism" forged by the monumental scale of the works. ${ }^{27}$ (One must kecp in mind that Serrano's meditations on the expressive potential of raumatized bodics and skin surfaces, viewed from obliquc or intenscly close angles, cannot be read solely as cvidence of unbridled artistic frecdom. Despitc the many aesthetic qualities to emerge from Scrano's the Morgue, his compositional choices (cspccially his suppression of the faces) must also be understood as necessities driven by fear of professional liability (if not his own, then that of the pathologist who allowed Serrano access to this morguc, the location of which has never been revealed).

Scrano's brutal cruncation of the corpses goes beyond a proclivity to fragmentation as a compositional paradigm. The acstherics maintain the viewer in a tcnsion-filled relationship, somewhere berween seduction and repulsion, with the images. I would like to bring attention to Scrrano's rejection of the humanist impulses of the Renaissance towards maintaining the dignity and integrity of the body. Likcwise, in Julia Kristeva's discussion of Hans Holbein the Younger's The Body of the Dead Christ in the Tomb (1522), she outlines how the humanist tradi-

tion is contravened because the holy corpse is left to solitude, unmourned, and denied the cxpectation of transcendence. 28 What Kristcva identifics as the feeling of "severancc" in Holbein's work is similar to the ponderous isolation that one senses with Serrano's corpses. Due to the anonymity through which Scrrano must structure his work, the corpses are disconnected from personal identity and biography, bereft of connotation alluding to family, community, and loved ones. Serrano's corpses exist in the here-and-now of the morgue and in the immediacy of photographic emulsion.

While some of the previously mentioned artworks (by Goldin, Wojnarowicz, and Bronson) could be considered contcmporary lamentations or P'ictas, in Serrano's play of references between divinc and criminal bodies in The Morgue, it is not the religious but the secular gencalogy of visual culcure that supplies more forceful connotation to the idencities of the dead. As with most of the works in the series, Scrrano's penetrating focus updates a history linking the dead criminal body to the science of anatomy, both in practice and in art-historical represcntations of it. Much scholarship brings attention to the laws that were introduced in the sixteenth century in England to allow the closely linked guilds of barbers and surgeons to perform dissections on the bodies of executed felons. ${ }^{29}$ As medical art historian Deanna Petherbridge demonstrates, the visualization 
of the corpse was founded upon the moralizing alignment of the anatomized body with the criminal, who was therefore subject to the loss of bodily privacy and dignity. Engravings by William Hogarth and others after him (fig. 3) became instances of memento mori (scencs of retribution for the crimes committed by the dead and reminders to the living not to follow suit), a view supported by the nooses that are depicted attached to the figures' necks and the way their remains arc, at times literally, fed to the dogs. ${ }^{30}$ Corpses of criminals were cut open for inspection not only in the anatomy theatre, which at times resembled a circus sideshow, but also through the work of artists who heightened the grotesque atmosphere of degradation to the body. How different is this historical scenario from the contemporary gallery environrnents where Serrano's corpses are put on display, subjected to public scrutiny?

Further, Micke Bal's study of Rembrandt van Rijn's painting The Anatomy Lesson of Dr. Nicolaas Tulp (1632)

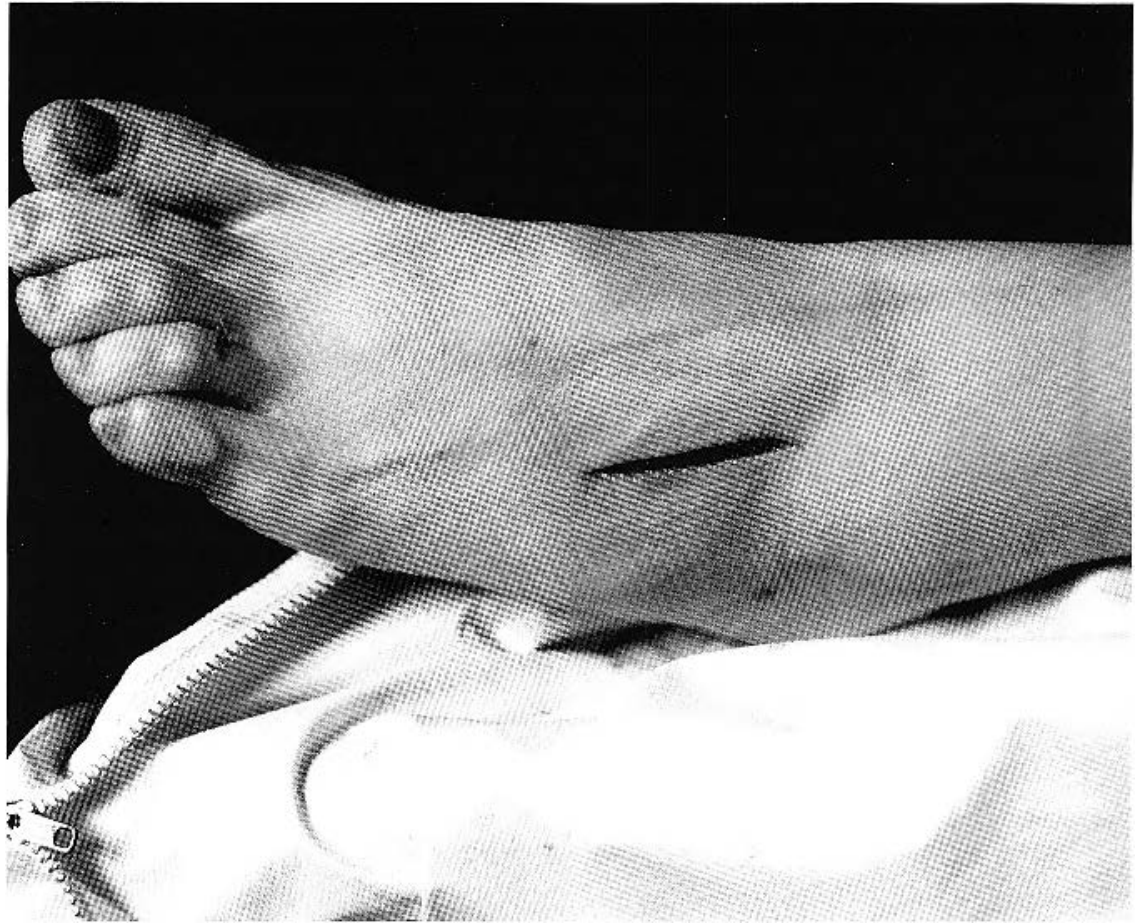

Figure 6. Andres Serrano, The Morgue (Rat. Poison Suicide, 11), 1992. Cibachrome photograph, $125.7 \times 152.4 \mathrm{~cm}$ (C) Andres Serrano; courtesy of the artist). (fig. 4) deepens our understanding of these power relations in the field of vision. Bal suggests that different levels of mastery are performed by figures who function as surrogate tropes for the deity: the surgeon animates the corpse by demonstrating the function of its constituent parts (herc, its hands), and stands in for the artist who, in his handling of paint, likewise holds a power of creation. ${ }^{31}$ Bal's reading centres upon the compositional nexus formed by the meeting of various hands, both the living surgeon's and the dead condemned criminal's. ${ }^{32}$ Additionally, in Michel Foucault's history of the science of pathological anatomy, The Birth of the Clinic: The Archaeology of Medical Perception (1973), one is made aware of a redoubling of various forms of manipulation and incision that is pertinent to Serrano's views of dead bodies cut up by wcaponry. 33 According to Foucault, the domination of the body inherent in the type of visuality that founds the tradition of anatomy is echoed by the literal cutting into the various tissues of the corpse by the anatomist. Serrano's work as a photographer is a contemporary counterpart to these structural relationships, involving a docile body and a professional set of artist's tools (the photographic apparatus, his own trained hands and eyes), which function to gain or convey a specific type of knowledge. Serrano's subject matter in Knifed to Death, I and Knifed to Death, II involves brutal contacts endured by the deccased (knife wounds on the arms), and subsequently, the violence of these contacts is paralleled by a photographic gaze that involves invasive close-ups and a visual fragmentation of the corpse. Scrrano's photographs not only depict skin but also are like delicate skin surfaces that can be punctured by an incisive photographic vision, so that the ripe and docile flesh of dead subjects is inscribed only with the artist's vision, without attempts made to compensate for the already violated perspectives of those he represents.

\section{Minimal Agency}

The works that comprise the Rat Poison Suicide trio necessitate a feminist reading because of the gendered specificity that adheres to thc corpses. These works demonstrate the consequences for a dead female, who is subject to a deterministic camera gaze that occludes the head and face while violently exposing the genitals. Identity, and the means of expression traditionally associated with the face (the locus for the eyes, the voice, and the agency they implicate), is overturned in favour of a reification of the deceased as a sexualized object whose genitalia and painful-looking wounds are treated as equivalents. In this section, I will demonstrate what happens with this type of "representation-by-occlusion." 
Because the face of the corpse is entirely hidden in Rat Poison Suicide, I (fig. 5), it has been one of the works that led one critic to say that Serrano has shielded the identity of the dead from violation: "Found in the freezer after rigor mortis had set in, she is shown with her head covered to protect her identity and her arms raised in the air." 34 Duc to the way Serrano fragments the figure and names the work after a colloquial version of the cause of death, he creates a comic-book awareness of the circumstances surrounding the figure's death. The multi-faceted qualities of the woman's identity and her history are reduced to the information conveyed by the title, a cipher of toxicity. With arms raised stiffly and both hands clenched in fists, the body's position is emphasized by the dramatic lighting from a hidden source behind the head, which is draped with a sheet and obscured by shadow. The hands, rising up like rat claws, present a view of the body that enacts a grotesque form of mimesis to reflect the substance that killed her. The specific pathology of the dead is performed through a horror-show morphology of her body, which circumscribes her identity along the lines of the lowly disease-ridden pest. This process becomes magnified within a gendered framcwork, when one takes into consideration Bronfen's assertion that the "feminization of demonised flesh is the material representation of alterity, of Woman as an animal creature." 35 By blacking out her face and head, Serrano contrives a figure that is monstrous, a quality that stems from a history of what was considered to be anomalously embodied femininity, which, as Rosi Braidotti points out, is closely linked with the definition of the pathological in the biological sciences. ${ }^{36}$ Because one is not provided information about the personal, psychological, or economic chain of events that led to this death, Rat Poison Suicide, I remains as distanced from the concrete reality of the subject's former life as it is remote from the viewer. Nevertheless, the woman's corpse-contorted by the bizarre coincidences that have surfaced in its position - seems to emit its own source of agency, due (ironically) to the clenched hands and the antagonistic crossing of the arms, as if putting up a fight. This suggests a posthumous defiance, if not against her own demise, then against the terms of visuality to which she has become subject.

Rat Poison Suicide, II (fig. 6) is an extremely close, horizontal vicw of the woman's foot, cropped from the tips of the toes to the anklc. This club-likc, fleshy mass, resting upon an unzipped, fluid-speckled body bag, suggests a ritual unveiling, but also reminds the viewer of the morgue context, lest one think this foot is a study taken from a live modcl. Across the top of the foot there is a deep cut that does not bleed, but tautly, provocatively gapes open, as if it were a pair of lips about to spcak. The focus of Rat Poison Suicide, $I I$ is less the foot than the wound, which constitutes the focal point of the image; the flesh merely offers a canvas for its appearance, like a grimace marring

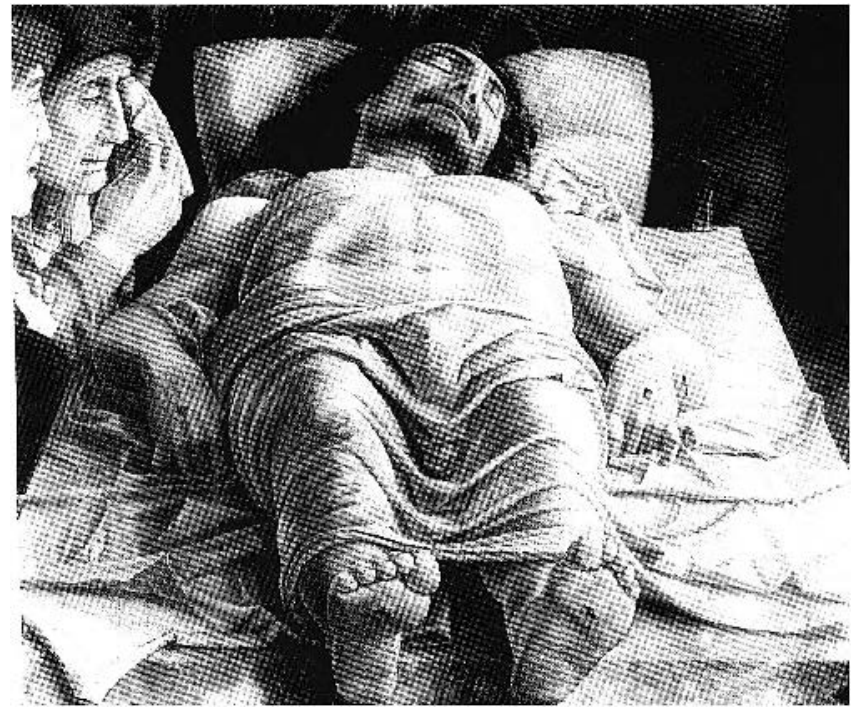

Figure 7. Andrea Mantegna, Lumentation of the Deod Christ, after 1466. Tempera on canvas, $67.9 \times 81 \mathrm{~cm}$ (Courtesy of Milano Pinacoteca Di Brera).

the skin's surface. In a way similar to the wounds on the bleeding hands in Knifed to Death, I and Knifed to Death, II, Serrano gives prominence to the gash that marks the foot ambivalently, as if by stigmata, if one recalls that to be stigmatized is not only to be divinely chosen, but also to be branded as a criminal and an outsider. The location of the cut and Serrano's focus on it distinctly suggest the iconic wounds Christ endured from the Crucifixion, so often made visible in the history of Western painting. Further, the ocular fixation on the foot of Serrano's corpse recalls the novel foreshortened pcrspective used by Andrea Mantegna to represent the Lamentation of the Dead Christ (after 1466) (fig. 7), such that one has the pcculiar opportunity to view the soles of Christ's feet, whose wounds from the nails are displayed prominently. Perhaps the iconic resonance of the wounded holy body lingers, but with Rat Poison Suicide, II, when one takes into consideration the apparent sex of the corpse (and the apparent cause of death), a less reverential and more injurious meaning emerges. The wound in Rat Poison Suicide, II is less the divine stigmatum of a Christ figure than the humiliating mar of a Hester Prynne, emblazoned by a Hawthornesque "scarlet letter" indicating sin rather than sainthood. While the aesthetic parallels between Serrano's work and Mantegna's are apparent, the symbolic content has been distorted by its gender specificity.

In light of Jane Blocker's interpretation of body artist Hannah Wilke's S.O.S. Starification Object Series (1974-82) (fig. 8), it becomes less possible to consider the wound on the foot of Serrano's female corpse in Rat Poison Suicide, II a divine mark 


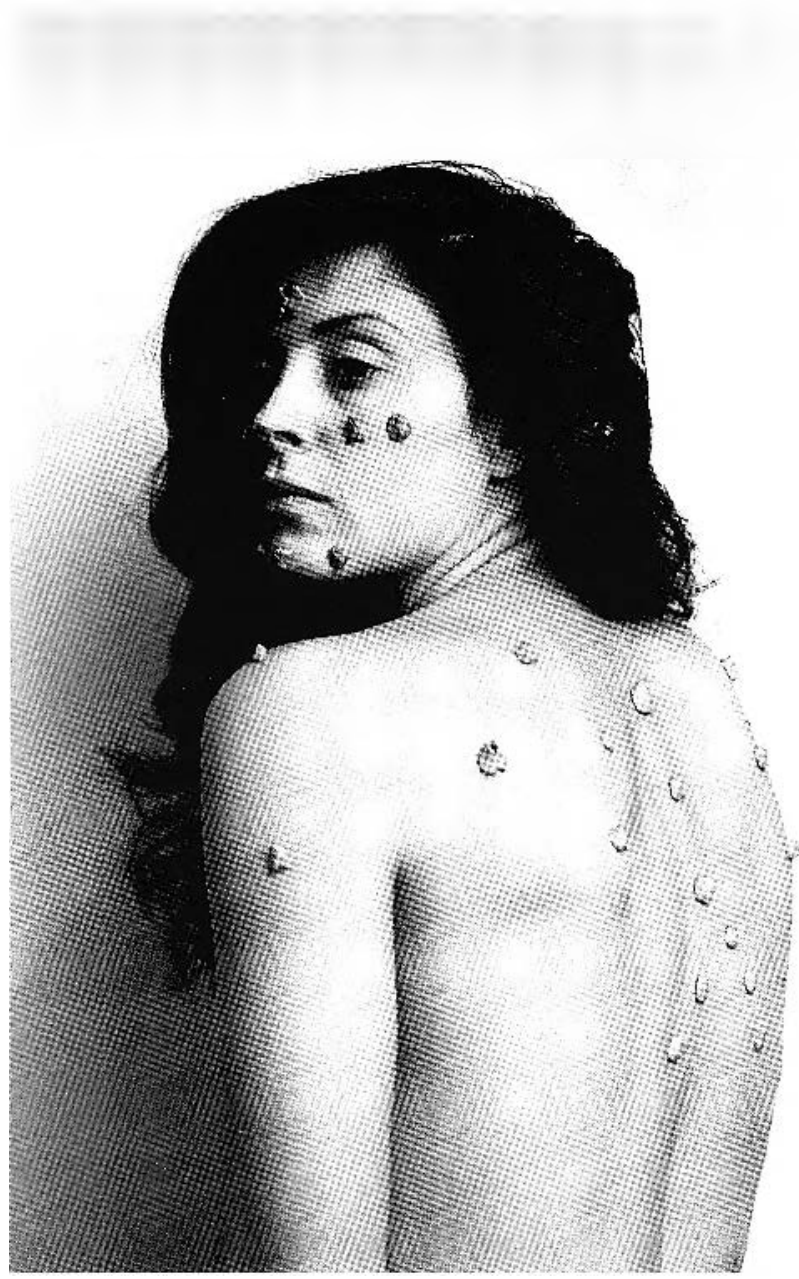

Figure 8. Hannah Wilke, Performalist Self-portrait with Les Wollam, S.O.S. Starification Object Series, 1974 (C) Marsie, Emanuelle, Damon and Andrew Scharlatt/VAGA [New York]/SODART [Montréal] 2007; courtesy of Ronald Feldman Fine Arts, New York).

but, on the contrary, a means of expressing suffering when a woman's voice has been silenced. ${ }^{37}$ In Wilke's S.O.S. Starification Object Series, pieces of chewed gum were looped and then stuck to the half-naked body of the artist, and she was photographed in various stereotypically feminine (coy or narcissistic) poses. According to Blocker, Wilke's work makes links berween the orifices of the female body (namely, "mouth/labia/ wound/scar"), so that they take on somatic resonance: in other words, so that they indicate the pain involved in the female's inability to express herself against social and cultural oppression. ${ }^{38}$ According to feminist theorist Janice McLane, wounds surfacing on the female body can, indeed, express suffcring; the actions of abused women who resort to cutting themselves in order to express their pain can be considered a "voice on the skin" when no linguistic opportunities exist-when one lacks agency. ${ }^{39}$ Following these insights, the wound and the mouth are linked vehicles of speaking, painfully, through the female body, a means of adaptation to various forms of silencing. The wound on the foot of Rat Poison Suicide, II can be understood as a means of contact with the dead. However, in lieu of the dialogic possibilities that would be suggested by a mouth, which offers a means of agency to speak about one's pain, a cut is depicted that will never heal, that will remain permanently open, offering merely an avenue of violation that structures the viewer's look. The intensity of Serrano's focus on the wound suggests that the camera eye has also contributed to this incision, which in turn guides the viewer's look to touch the dead woman's body only there, at this vulnerable "opening." Because Serrano crops the foot so radically from the rest of the body, the only means of access the viewer has to the identity of the woman, and to the matcrial, biographic conditions that inform her present condition, is through the wound-a painful orifice for expression.

When seen sequentially, the third work to comprise the Rat Poison Suicide suite offers an unprecedented tour of a headless, violently fragmented, female body (fig. 9). Serrano introduces a temporal elcment because he shows the corpse before and after the autopsy procedure. This is made evident by the massive incision along the length of the naked torso, from throat to genitals, brutally sewn closed to resemble the rungs of a ladder. With the corpse displayed from a lateral perspective between her truncated thighs, the viewer's look starts at the vagina and is directed over the torso by the incision itself, which is crowned by the body bag covering her face. The work therefore completes the trio of works (if one views them in sequence) by offering "closure" to the experiences of the corpse, suturing the body through a series of views that represent all her extremities with the exception of her head. The white brassiere from the first image has been removed and the white body bag opened to frame the corpse, which is at once shrouded and uncovered by Serrano's manipulation of the drapery. The body bag is rolled up over her face and then parted at the sides to fall around the figure as if suggesting, in a hideous way, the veil of a bride.

With Rat Poison Suicide, III, the foreshortened perspective alludes directly to the position of the corpse of Mantegna's Lamentation of the Dead Christ, but with a more aggressive violation of the latter's classicism because the body only begins at the thighs and is then decapitated by the hooding of the body bag. The camera's focus is centralized on the vagina and, by way of the post-mortem scar, moves along its trajectory to arrive at the knot of fabric offered in place of the head-the literalization of a vanishing point. With such works as Serrano's Gun Murder (illustrated in Douglas's article), the art-critical discourse 


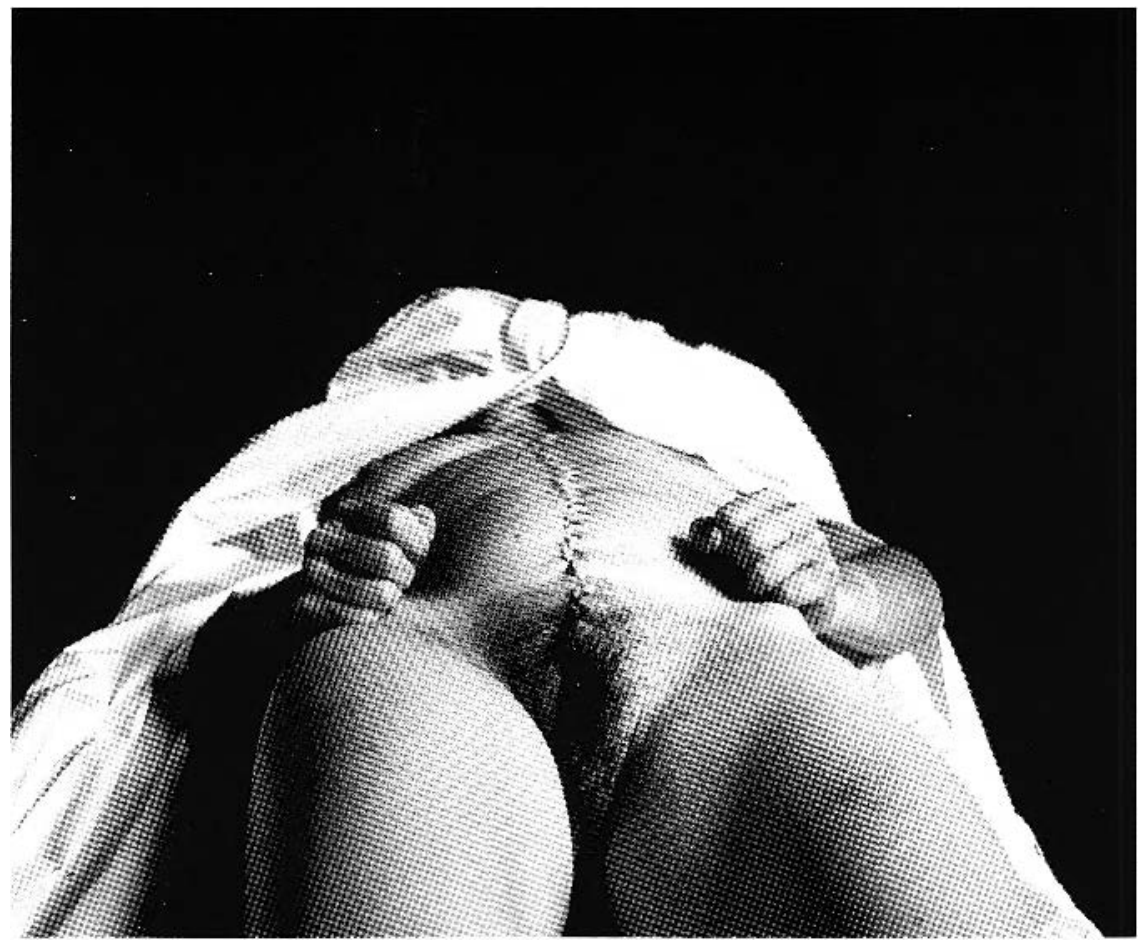

Figure 9. Andres Serrano. The Morgue (Rui Poison Suicide, III). 1992. Cibachrome photograph. $125.7 \times 152.4 \mathrm{~cm}$ (C) Andres Serrano: courtesy of the artist).

has rightly made links between the history of painting and the realistic portrayal of the mortally wounded male body. However, the comparison that has not yct been made is between the violated female corpses of Serrano's The Morgue and another history of representation-that starting with the anatomical illustrations of the Enlightenment and leading to a notorious sct of modern artworks.

In its deadness, facelessness, "sawn off legs" and "exposed pudendac," Scrrano's anterior perspective in Rat Poison Suicide, III resembles the medical illustrations of gravid uteruses from the eighteenth century as described by Petherbridge, such as those found in William Hunter's atlas, drawn by Jan van Rymsdyck (fig. 10). ${ }^{40}$ While Petherbridge views the openness of the gravid uterus drawings as representations of the "absent body" of the woman, I would argue that Serrano's Rat Poison Suicide, III presents an "all body" view of the woman, not sliced open but rather sewn closed. The emphasis on the sewn-up skin of the corpse (an unseemly seam), evokes touch in a manner resembling that of Rat Poison Suicide, II because it structures the corpse by an cxcessive vulnerability. The painful-looking "incision-closure" appears to confine the identity of the woman to the bluntness of a body, as if trapping her in it. At the same time, Serrano's photographic approach exposes her in a disturbing way-by prodding her and prying her open for view. Bc- cause the woman's face has been occluded in favour of a grossly invasive view of her pubic region, the deccascd is not represented as a subject but as a spectacular display of her sex. As such, she contributes to the legacy of masculinist representations of female genitalia, fragmented from the rest of the body and easily penetrated, in a way that closely recalls Gustave Courbet's L'origine du monde (1866, Muséc d'Orsay), as well as Marcel Duchamp's Étant données (1946-66, Philadelphia Museum of Art). 41 This view is supported by Susan Ciubar's interpretation of René Magritte's Surrealist painting l.e viol (1947, private collection), an cqually literal defacing of a woman by her sexual parts, in which the breasts stand in for the eyes and the vagina replaces the mouth: a violent, fetishized fragmentation of the female figure that disallows her any imagined sense of agency (that associated with, for example, the look or the voice). 42 It is this legacy of representations-specific to the femalc body-that should be recognized as positioning Rat Poison Suicide, III as yet another "beaver shot" to populate the history of modern art, all under the auspices of a scandalous pornographic exposure.

The sense of indecency surrounding Rat Poison Suicide, III involves the rigidity of the closed thighs and the tightly clenched fists, which rest on the jutting hip bones and act as gatekeepers of the corpse. These aspects of the body, coupled with the display of the scwn-up "insides," seem to rcfuse the camera's eye and suggest an attempt to ward off any scopic approach. The clenched fists constitute the site where the dcceased's loss of agency appears to be resisted from beyond the grave, as if expressing outrage. Closed in gestures of guarded interiority and white-knuckled refusal, they are different from the languid openness of the hands in Knifed to Death, I and Knifed to Death, $I I$, and the foot in Rat Poison Suicide, II. The rigidity of the corpse's extremitics in Rat Poison Suicide, III offers it a singular degree of posthumous agency to counter its clinical invasion, as well as Serrano's visualization of its aftermath, to offset the silencing of the voice and lack of access to the gazc caused by Serrano's draping of the face. Despite art historian Paulo Fabrii's good suggestion that one explore areas of the body other than the face to discover expressive possibilities for the emergence of human identity, the suite of Rat Poison Suicide photographs does not offer a solution to the ideological problems associated 


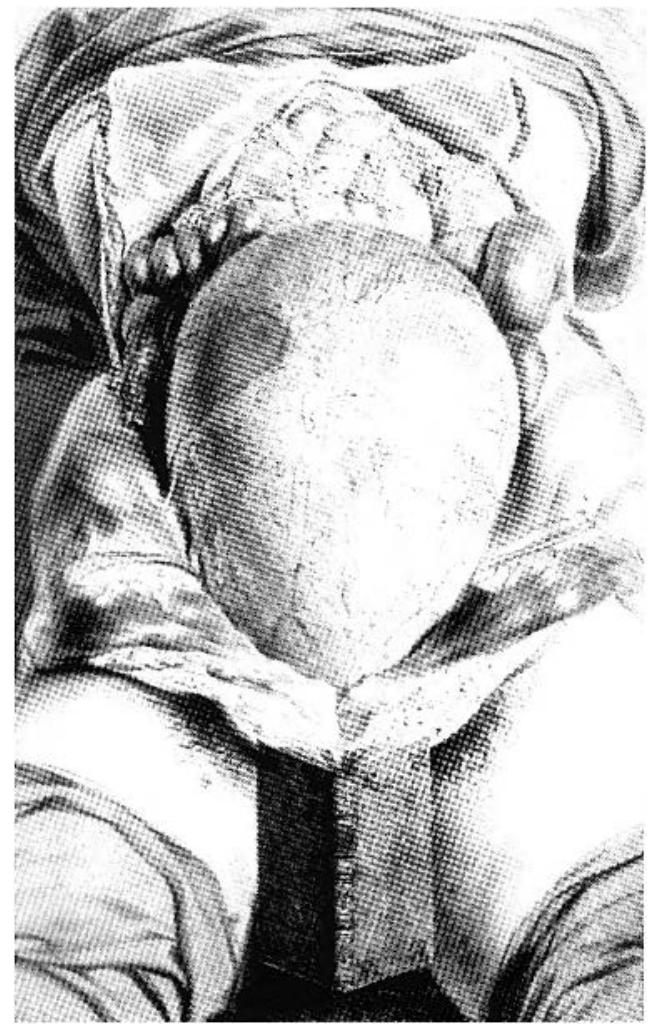

Figure 10. Jan van Rymsdyck, drawing for $X X V I$ in William Hunter, Anotomy of the Human Grovid Uterus, 1774 (Courtesy of Glasgow University Library, Special Collections [Az.l.4])

with the face as an index of personality.13 In fact, the photographs exacerbate the problems associated with the legacy of representations that turn woman into a body-one probed necessarily for forensic purposes, but also violated unnecessarily for artistic ones.

\section{Subjectivity in (De)composition}

Serrano's series appeased critics by the way he apparently hid the identities of the dead (as if the face were the locus of identity). Jane Doe, Killed by Police (fig. 11) is the "remarkable exception," because the face of the woman is shown. ${ }^{44}$ This work is a closely cropped, horizontal view of a woman's face, photographed at close range and in stark profile, where many distinguishing "features" of her countenance are exploited, most notably its advanced stage of decay. Curator Daniel Arasse has referred to this work as a "portrait," an ironic term for a figure with a generic name signifying nothing more than the fact of her anonymity. 45 Arasse is referring, of course, to the idea that by exposing her face, her identity is made visible. Perhaps Serrano felt he could expose the facial features of Jane Doe because, at this stage of dccomposition, her peeling skin is only a surface with no connection to the "depths" of her identity.

Striking are the rings and blotches of peeling, discoloured skin, and the spotted markings in shades of brown, beige and red, which transform the woman's face into a mask of camouflage. In the darkencd space directly above her car onc finds a gunshot wound, blackened around the edges and still glistening in the centre. Serrano must have chosen the profile perspective to heighten the visibility of this cavity, offering one of many visual nodes to which the viewer's look is drawn. He has cropped the image at the chin, effectively beheading the woman in the visual register, separating the head from any sense of the body or clothing, and creating a monumental objectification, a Medusalike decapitation. According to Edward Lucie-Smith, Serrano's work directly references the Romantic tendencies of Théodore Géricault's art with a "close and not accidental resemblance to the celebrated still lifes of piled-up severed body-parts." 46 I would point out that it is Serrano's photographic framing that causes this effect of sevcrance, that forces the body to be viewed in parts. Unlike the severed limbs and heads secn in Géricault's works, those in Serrano's The Morgue are, with few exceptions, not themselves dismcmbered, but only appear to be so due to his aesthetics of fragmentation.

According to Serrano, the woman was actually black but, as the morgue pathologist explained to him, apparent racial features of the skin become misleading when a body is in a state of decomposition. ${ }^{47}$ The polychrome, decaying skin, flaking off and becoming unrccognizable, does not solicit the viewer's touch, but rebuffs it, and offers a repellent surface that alludes to an underlying corruption. According to Bronfen, the historical association of femininity with moral decay traces a lineage back to the Biblical figure of Eve. ${ }^{48}$ The skin of Jane Doe exists as a death mask and, as such, a sinister meaning arises because the mottled, spotted skin creates an emblem of pathological decay, a misogynistic trope of femininity's underlying link to death. Further, Sander Gilman identifies the way social stereotypes function along binary lines, and has identified the various forms of pathology that adhere to deviations from the dominant norms of race, class, ethnicity, body morphology, and health (particularly mental health). ${ }^{49}$ According to Gilman, what is most pernicious about the attribution of pathology is how it stigmatizes women, people of colour, and the mentally ill in terms of a debased morality: "The very concept of pathology is a line drawn between the 'good' and the 'bad."'s0

Despite the fact that few of the deaths in The Morgue are attributed to physical illness, a view of these corpses as inherently pathological is strong, due to the various forms of linked "depravity" that enshroud them, especially suicide and violent crime. The morgue context puts all the corpses under suspi- 
cion, compounding one form of pathology upon another in this image (layering violence, gender, and race), and making them speak through the body, as if bringing pathology to the body's surface. The corpse of Janc Doe is made to perform her "pathology" in a way that is ultimatcly closely aligned to the debunked tenets of phrenology and physiognomy and the historical, instrumcntal function of mug shots, in the service of various institutions (the prison, the asylum, the hospital), the ideological imperatives of which have becn described by Allan Sekula. ${ }^{51}$ All of these horriblc coincidences make difficult any critical recourse to postmodern theories of identity, in which racc or gender are intcrpreted as largely culturally constructed and therefore open to resignification, rather than as essential, natural, and incvitable. Here, Jane Doe has no such agcncy. Any attempted critique of racism (i.e., that its foundation is, in Serrano's phrase, "only skin deep") becomes a peril-



Figure 11. Andres Serrano, The Morgue (Jone Doe, Killed by Police), 1992. Cibachrome photograph. $125.7 \times 152.1 \mathrm{~cm}$ (@) Andres Scrrano; courlesy of the artist). ous move because Serrano does not grant

his subject enough agency to mount a protest. 52 Because the work is founded upon an initial violation, Serrano's ironic observation of the woman's race gains no momentum.

One of the most compelling aspects of Jane Doe, Killed by Police is the woman's sightless cyes and their submersion into her face. What appears to be a desiccatcd contact lens rests uselessly on her lower eyelashes, as if the corpse is emitting plastic tears. Among all the works in The Morgue, Jane Doe, Killed by Police is the only one in which a woman's eyes are visible, suggesting Scrrano's attraction to this particular instance of sightlessness, the deformity of her look. Scrrano plays upon the agency of the gaze, but only to emphasize the extent to which the body in Jane Doe, Killed by Police is denied the intersubjectivity that the gaze fosters. As with Knifed to Death, I and Knifed to Death, II, this paradox is conveyed in a tautological way. Just as Serrano focuses on the dead, senseless hands that could no longer fcel the touch of the ink on its fingertips, so with Jane Doe, Killed by Police he focuses on the sunken eyes, frozen by the work of photography, but also sightless in the woman's mortality and unable to acknowledge the penetrating looks of the viewer. In his discussion of a mode of intersubjectivity in which vision is nuanced by touch, Jacques Derrida suggests the divergent typcs of contact that can occur between two subjects: "Si deux regards viennent au contact, l'un de l'autrc, on se demandera toujours s'ils se caressent ou s'ils se donnent un coup, et où serait la dif- férence." 53 In its ethical and phenomenological underpinnings, Derrida's insight suggests the various types of contact - wounding or gentle - that are possible between two subjects (here, the photographer and his subject), and the extent to which Serrano's approach is one-sided and monologic rather than dialogic. The visuality that informs Serrano's artistic paradigm is infused with proximity, but of a wounding type, without any sense of reciprocity. The cyclc of violence is thus completed by the photograph, whose precision of focus cchoes that of the gunshot wound: the bloodied, black hole into which the woman's former identity is engulfed.

As Jane Doe, Killed by Police makes clear, subjects arc vulnerable to the painful effects of embodiment, and to the worst kind of mortal violence. However, bccause subjectivity is also a theoretical premise, subjects arc vulnerable to the effects of discourse and representation. What happens when one is "named" by remaining unclaimed, unidentified, or wrongly named? The title Jane Doe, Killed by Police leaves the woman with the "identity" of the unknown because her corpse was neither claimed by family members nor signified with a proper name. Judith Butler's theories are useful to account for the painful effects of being named, not only with proper names but also with descriptive terms: effects to which Janc Doe becomes subject, despite her apparent anonymity. Butler's corporalization of language in Excitable Speech makes evident a particular vulnerability in the 
discursive field, so that language appears to act in a dualistic way, where "linguistic agency" can quickly descend into "linguistic vulnerability" when the name one is called is wounding. 54 The act of naming is centrally important because it confers existence to a subject or, in the case of the temporary "misnomer" conveyed by Serrano's title Jane Doe, Killed by Police, affixes her with a nominal identity that is simultaneously a derogation. The dual potential (either "inaugurative" or "descriptive") involved with any name suggests how the identity of Jane Doe is structured in the public field through the names she is and is not called.55 Ihose names direct her identity along disparate paths.

There is no question that the deceased is silent, but were friends or family members given the opportunity to voice opinions that would present a fuller view of her identity? Not only does she remain victimized and criminalized, but also, in her lack of representation by friends or family members, she becomes subject to social alterity rather than affiliation. As Kylie Rachel Message states, it is the name that causes the sense of injury: "Not simply dead and unseeing, this woman is identified or named exclusively by her death. She is called not simply Jane Doe but The Morgue (Jane Doe, Killed by Police). The brutality of her death encroaches upon, and indeed encompasses, any subjectivity she may have had whilst living." 56

Literal identification is further complicated for the simple reason that to claim Jane Doe would be potentially to implicate oneself in the crime because, according to Serrano, she was sought by police and apprehended in a stolen vehicle. Her nominal status as Jane Doe reduces her to the realm of those unloved bodies that remain in the morgue freezer for months, lacking figures to gather their remains or to advocate on their behalf, to clear their names from criminal implication. ${ }^{57}$ Jane Doe and her family are reduced by the way her body exists in oppressive solitude, without anyone to qualify or refute the connotation of Serrano's seemingly transparent photographs, where anonymiry becomes a source of violation rather than a protective shield. This situation is exaggerated with representations of the dead because they are not in a position to claim or refuse names for themselves, but are entirely vulnerable to this posthumous activity.

Only one critic, Peter Schjeldahl, has complained that no surrogates for the dead were given the opportunity to authorize or refuse the works in Serrano's series: "Be it added, on this score, that a posthumous vulnerability-circumstances of death mandating a coroner's opinion or just negligible social statuslanded these deceased ones in a morgue whose security proved nonchalant." 58 This situation, the delicate and easily degraded status of the dead, contributes to their "posthumous vulnerability," as we have seen unfold in the The Morgue series. My concern has less to do with the logistics through which these works are realized (Serrano's access to and non-consensual engage- ment with the corpses) than with Serrano's aesthetics, which transform the identities of the deceased into specters, if not also specimens, immortalized by the lens of pathological violence.

Whilc it is obvious that the dead are lacking the agency necessary to claim and assert an identity from their perspective, the various ways in which certain identities are imposed upon them are worthy of closer consideration. When considered in terms of the dead, the forcible process of subjectivity is put into relief. The dead can neither self-represent nor experience the recognition of living others who see them, name them, or create pictures of them. Because the dead have no recourse to agency, they can neither recognize that the subjective process is occurring, nor can they attcmpt to qualify or counter its effects by asserting identities from their own points of view. Despite their absence from the scene of subjectivity and from the social-temporal matrixcs through which subjectivity unfolds, the dead are still "named" by its effects, through representations in myriad systems that run the range from reverence to injury. Serrano's representations indicate a point where agency (as it involves embodiment, the expression of identity, and the emergence of subjectivity) is evacuated - foreclosed from the sidc of the dead and deployed and enjoyed only by the artist and viewers-so that representational pcrspective is unilateral and the dead are left both defenceless and radically other.

\section{Acknowledgements}

I thank Ananda Shankar Chakrabarty for his translation of the abstract and for proofreading. Information regarding forensic morgues was provided by Christian Kiriakos, Coordinator, Decedent Affairs Office, Boston Medical Centre, and Brendunt (Rocky) Tilgham, Mortuary Supervisor, Massachusetts State Medical Examiner's Office, Boston, in October 1998. These interviews and tours of the facilities were arranged by Dr. Michael O'Brien (to whom I am extremely grateful), Chief of Pathology at the Mallory Institute, Boston University School of Medicine. I would also like to thank my father, Dr. Garry F. Fitzpatrick, $\mathrm{MD}$, whose support of this research and requests on my behalf led to the above interviews. This writing is dedicatcd to his life's work as a general surgeon with a specialization in trauma care. I would like to commemorate, with love and admiration, his 2007 retirement from the Boston Medical Center and from the Veterans Administration Healthcare System in Massachusetts.

\section{Notes}

1 Michael Dibdin, "The Pathology Lcsson," Granta 39 (1992): 97.

2 Dibdin, "The Pathology Lesson," 97.

3 Elisabeth Bronfen, "Violence of Representation-Representation of Violence," in Over Her Dead Body: Death, Femininity and the 
Aesthetic (Manchester, 1992), 39-55.

4 Daniel Arasse, Andres Serrano: The Morgue, trans. Sheila Malovany Chevallier (Paris, 1992); Christine Bernier et al., L'Image de la mort: Aux limites de la fiction: l'exposition du cadavre, Actes du colloque tenu au Musée d'art contemporain de Montréal (Montréal, 1994); 7denka Badovinac, Andres Serrano (Ljubljana, 1994); Susan Douglas, "In Camera, Andres Serrano," Parachute 78 (April/ May/June 1995): 12-19; l'aulo Fabrii, "Deformities of the Face," in Identity and Alterity: Figures of the Body 1895-1995 (Venicc, 1995), 27-31; Mel Gooding, "Sense and Sensibility," Art Monthly 190 (October 1995): 8-13; Eleanor Heartney, "Postmodern Herctics," Art in America, February 1997, 33-39; Adam LeBor, "Andres Serrano," Aperture 138 (Winter 1995): 48-49; Kylie Rachel Message, "Watching Over the Wounded Eyes of Georges Bataillc and Andres Serrano," in Images of the Corpse: From the Renaissance to Cyberspace, ed. Flizabech Klaver (Madison, 2004), 113-32; Patrick Murphy et al., Andres Serrano: Works 1983-1993 (Philadelphia, 1994); E. Annie Proulx, "Dead Stuff," Aperture 149 (Fall 1997): 30-35; Jerry Salt7., "Andres Serrano ar Paula Cooper," Art in America, May 1993, 124-25.

5 Because identity has been linked with notions of sameness, unity, oneness, essence, implying origins, ontology, consistency or immutability rather than change, morphological certainty, solipsism, internal forces and foundations, it has been debated and frequently criticized as working against the best intcrests of feminists, gay and lesbian rheorists, and theorists of race and ethnicity who explore this notion. The term différance, inspired by Jacques Derrida and luce Irigaray, is often strategically used in lieu of identity. See D)iana Fuss, Essentially Speaking: Feminism, Nature and Difference (New York, 1989) for an analysis of this situation. For onc of the most comprehensive articulations of a view against "substantive," "foundational," or "ontological" conceptions of identiry, sec Judith Butler, Gender Trouble: Feminism and the Subversion of Identity (New York, 1990). 'Ihere is a significant amount of literature negoriating other ways of conceptualizing idencicy through multiplicity, heterogeneity, difference, fluidity, or flux. Of this stream the most widely recognized thinker is Luce Irigaray, who has influenced the thinking of Christinc Battersby and Drucilla Corncll. For other analyses of the various pros and cons of these positions, see the diverse viewpoints in Feminists Theorize the Political, ed. Judith Butler and Joan Scott (New York, 1992); and Feminist Consequences: Theory for the New Century, ed. Flisabeth Bronfen and Misha Kavka (New York, 2001).

6 Elizabeth Grosz, "Drucilla Corncll, Identity, and the 'Evolution' of Politics," Time liavels: Feminism, Nature and Power (Durham, 2005), 85.

7 Grosz, Time Travels, 88.

8 Kath Woodward, Questioning Identity: (iender, Class, Nation (London, 2000), 6.

9 According to Woodward: "The subject, 'I' or 'we' in the identity equation, involves some element of choicc, however limited. The concept of identity encompasses some notion of human agency: an idca that we have some control in constructing our own identities" (p. 8). For views that affirm the potential for agcncy attendant in notions of identity in the visual arts, see Audre Lorde, Sister (Outsider (Trumansburg, NY, 1984); bell hooks, Black Looks: Race and Representation (Boston, 1992); Jo Spence, Cultural Sniping: The Art of Transgression (London, 1995): David Wojnarowicz, Close to the Knives: A Memoir of Disintegration (New York, 1991); Russell Ferguson et al., cds., Out There: Marginalization and Contemporary Cultures (New York, 1990).

10) Judith Butler has theorized identity in relation to agency in a manner that makes the relationship extremely complex. Butler's belief is that identity should not be thought of as "voluntarist," i.e., as individuals merely "taking on a mask," but as "a signifying practice" that always presupposes an existing ficld of regulatory social norms and relations. See Butlcr, Ciender 'irouble, 145, and Bodies That Matter: On the Discursive Limits of 'Sex' (New York, 1993), 7. For Butler, however, agency is nor something one has or can deploy; it exists only in the limiced potential for subversion in relation to the confines of the social matrix that precedes the subject-it occurs within the cracks, slippage, and failed attempts made by the subject to negotiate the restrictive standards of imposed gender identifications.

11 Butler, Bodies that Matter, 3.

12 Judith Butler, Excitable Speech: A Politics of the Performative (New York, 1997).

13 Burler is referring to a school of thinking concerned with "performatives," i.e., speech acts (as theorized by J.L. Austin, Jacques Derrida, and Roland Barthes), institutional statements that "do what they say," that bring the subject into linguistic existence by the institutional or social recognition of names (i.e., the verbal affirmations of religion or the law such as "I hereby pronounce you married," or, in medicinc upon the birth of a child, "It's a girl!").

If Bucler, "Introduction," Bodies that Matter, 1-23.

is Judith Butler, Gender Trouble; Bodies That Matter; Excitable Speech; The Psychic Life of Power: Theories in Subjection (Stanford, 1997). Bucler's thinking is influenced not only by linguistic notions of the performative after Barthes, 1)crrida, and Austin, but also by Lacanian psychoanalysis, and the genealogical thinking of Foucault, after Nierzsche.

16. Judith Butler, Precarious Life: The Powers of Mourning and Violence (London, 2004), 26.

17 Susan Douglas, "In Camera, Andres Serrano," Parachute 78 (April/ May/June 1995): 17.

18 Deaths that are considered suspicious are those that occur within twenty-four hours of being admitced to hospital, for instance, overdoses from narcotics, accidents (like drowning, fires, or auto fatalities), violent deaths, suicides and suspected suicides, or any accidents whose causes are unclear. 
19 Eugene A. Arnold, "Autopsy: The Final Diagnosis," in Images of the Corpse, 14.

20) Hobbs, Andres Serrano: Works 1983-1993, 42.

21 Douglas, "In Camera, Andres Serrano," 14.

22 Douglas, "In Camera, Andres Serrano," 12.

23 Douglas, "In Camera, Andres Serrano," 15.

24 Douglas, "In Camera, Andres Serrano," 15.

25 Douglas, "In Camera, Andres Serrano," 12.

26 Steiner, Andres Serrano: Works 1983-1993, 11.

27 Serrano's stated intention regarding the monumental scale, Andres Serrano: Works 1983-1993, 37.

28 Julia Kristeva, "Holbein's Dcad Christ," Fragments for a History of the Human Body, Part One, ed. Michel Feher (New' York, 1989), 239-69.

24 Katc Cregan, "Blood and Circuses," in Images of the Corpse, 39-62; Deanna Petherbridge, "Art and Anatomy: The Meaning of 'lext and Image," in The Quick and the Dead: Artists and Anatomy, with Ludmilla Jordanova (Berkelcy, 1997), 34.

30 Jordanova, "Happy Marriages and I)angerous Liaisons: Artists and Anatomy," in The Quick and the Dead, 104.

31 Micke Bal, "Dcad Flesh, or the Smell of Painting," in Visual Culture: Images and Interpretations, ed. Norman Bryson, Michael Ann Holly, and Keich Moxcy (Massachuscts, 1994), 365-83.

32 Bal, "Dead Flesh," 378

33 Michel Foucault, The Birth of the Clinic: The Archaeology of Medical Perception, trans. A.M. Sheridan Smith (New York, 1994).

31 Hobbs, Andres Serrano: Works 1983-1993, 42.

35 Bronfen, Over Her Dead Body, 68.

36 Rosi Braidotti, "Mothers, Monsters and Machincs," Nomadic Subjects (New York, 1994), 75-94.

37 Jane Blocker, What the Body Cost: Desire, History, and Performance (Minneapolis, 2004).

38 Blocker, What the Body Cost, 41.

39 Janice McL ane, "The Voice on the Skin: Self-Mutilation and Merleau-Ponty's Theory of Language," Hypatia (Fall 1996): 107-18.

40 Petherbridge, The Quick and the Dead, 84-86.

41 On these two works, see Amelia Joncs, Postmodernism and the Engendering of Marcel Duchamp (Cambridge, 1994), 191-98; and Linda Nochlin, "Courbet's Lorigine du monde: 'The Origin Without an Original," October 37 (1986): 76-86.

42 Susan Gubar, "Representing Pornography: Feminism, Criticism, and Depictions of Female Violation." Critical Inquiry XIII, 4 (1987), 723.

43 Fabrii, "Deformities of the Face," 27-31.

仵 Another horrific example of Serrano's uncovering the face of the dead is the two-part Broken Bottle Murder, which graphically depicts the results of violence at close range: a male head sevcred from its body rcsting upside down so that all the facial features are folded upon themselves like the wrinkles of a Shar-Pei dog. The pendant shows the scalp that has been ripped from the head, appearing as a curved, smooth expanse of pink flesh, forlorn and abject in the way it is flung to the perimeter of the framc.

45 Arasse, Andres Serrano: The Morgue, n.p.

46 Edward Lucie-Smich, Visual Arts in the Twentieth Century (New Jersey, 1997), 381.

47 Andres Serrano, public lccrure, Kodak Lecrure Scries, Ryerson University, Toronto, 12 March 2004.

48 Bronfen, Over Her Dead Body, 67.

49 Sandcr Gilman, Difference and Pathology: Stereotypes of Sexuality, Race, and Madness (Ithaca, 1985).

50 Gilman, Difference and Pathology, 23.

51 Allan Sekula, "The Body in the Archive," October 39 (1986): 3-64.

52 Serrano lecture.

53 Jacqucs Derrida, l.e toucher, Jean-Luc Nancy (Paris, 2000), 12.

54 Butler, Excitable Speech, 2.

55 Butler, Excitable Speech, 33.

56 Message, "Watching Over the Wounded Eyes of (icorges Bataillc and Andres Serrano," 129. Rather than suggesting the need for an ensuing ethical relation with the dead, Message suggests that the deceascd will be pushed away in a classic (Kristevan) process of abjection: "This violent death is what we must avert in order to live."

57 The "Jane Doe" stacus of this corpse alludes to a sense of degradation cven within the context of a working morgue and its layout (if the Coroner's Office in Boston is any indication) becausc unidentified bodies, which must be preserved for potentially extended periods of time, are kept in a special room whose temperature is lower than the regular holding areas. This ultra-refrigerated room is affectionately called among morgue staff the "de-co" room, referring to the extensive decomposition of the bodies, whose condition often precludes easy identification. This is another indication of how the status of the unidentified involves a physical scquestering of their remains nuanced by a grotesque linguistic distinction.

58 Peter Schjeldahl, "Art After Dearh," Village Voice, 16 February 1993, 91 